Author's post-print version

Published in the Journal of Documentation, Volume 74, Issue 6, 8 October 2018, pp. 11491161

\title{
Art as Document: on Conceptual Art and Documentation
}

\begin{abstract}
Purpose: The purpose of this paper is to bring the work of Seth Siegelaub (19412013) to the attention of document studies. Siegelaub was a pioneer of the conceptual art movement in New York in the 1960s, active as an art dealer, curator and publisher. He is remembered by art history for his exhibition catalogues, which provided a material base for intangible works of art.

Design/methodology/approach: This paper uses a comparative approach to examine the documents of conceptual art, especially the exhibition catalogues produced by Siegelaub between 1968 and 1972. Drawing on literature from document theory and art history and criticism, it examines several of Siegelaub’s key exhibition catalogues and books.
\end{abstract}

Findings: Siegelaub's theories of information have much in common with the documentalist tradition. Siegelaub’s work is important, not just for its potential to contribute to the literature of document theory. It also provides a point of dialogue between art history and information studies.

Originality/value: To date, the common ground between art and documentation has been explored almost exclusively from the perspective of art history. This paper is among the first to examine conceptual art from the perspective of document theory. It demonstrates potential for cross-disciplinary collaboration. 
Keywords: Seth Siegelaub, conceptual art, exhibition catalogues, documentation, primary information, document analysis, art theory Paper Type: Conceptual paper

\section{Introduction}

Since Michael Buckland (1997) published his landmark article 'What is a “Document”?', there has been a regular growth in conceptual literature exploring the theoretical and historical aspects of documentation. This body of work has tended to focus on questions of definition and problems arising from the material and signifying properties of documents (Lund, 2009). More recently, this literature has grown to accommodate alternative philosophical perspectives, with phenomenology providing a useful conceptual framework (Latham, 2014; Gorichanaz and Latham, 2016). However, to date, insights from art history and aesthetics have been noticeably absent from the documentation literature. This omission is surprising, given the close historical and intellectual kinship that evidently exists between art history and information science. Thus far, the common ground between art and documentation has been explored almost exclusively from the perspective of art history (Spieker, 2008; Berrebi, 2014; Santone, 2016; Berger and Santone, 2016).

Art history, and its cognate profession art curatorship, underwent a process of professionalization and institutionalization at approximately the same time as information science, commencing in the late nineteenth-century (Mansfield, 2002; Rubin, 2010). As a modern discipline, art history deployed scientific methods as a means of establishing its credentials among the traditional humanities and the so- 
called human sciences (Preziosi, 1989). Documents and systems of documentation were integral to the establishment of a robust and disciplined study of artworks and artefacts. Comparable to bibliography and systematic cataloguing in librarianship, catalogues played a crucial role in art history's professionalization in academic and museological settings.

However, in the late 1960s, art catalogues were liberated from their scholarly domain. No longer confined to the realms of the art museum and the academy, the exhibition catalogue was transformed by conceptual artists to serve a radical new agenda. Two related trends converged to challenge the supremacy of the physical and original work of art, especially its commodity status in the art market system. The terms de-aestheticization and dematerialization were coined to describe these tendencies. From this time, visual artists began to incorporate language, film and sound into the process of art production, often by substituting regular works of art for textual and video documents. Noël Carroll (1993, p. 316), a philosopher of art, described these changes as a shift from the idiom of phenomenology to semiotics and post-structuralism, whereby the basic constituents of art were no longer identified as lines or colour, but rather signs. Developments in contemporary art practice therefore necessitated a reappraisal of the role of the exhibition catalogue, especially its documentary relationship to the primary work of art. Performance art exemplified this problem. In this case, the work of art was presented to the audience as an action rather than an object. Because, like theatre, performance art took place in real time and was therefore impermanent, it could only be experienced afterwards in documentary terms, through photographic, textual, oral and video traces (Jones 1997). 
Drawing on literature from document theory and art history and criticism, this paper uses a comparative approach to examine several of Seth Siegelaub’s key exhibition catalogues and books, produced between 1968 and 1972. It aims to demonstrate important similarities between Siegelaub’s theories of information and those of the documentalist tradition, especially Michael Buckland's (1991) theory of information. Seth Siegelaub (1941-2013) was a New York art dealer, curator and publisher. He is best known in art history as a central figure of the conceptual art movement, where he worked closely with the pioneers of conceptualism, including Douglas Huebler, Lawrence Weiner, Robert Barry, Joseph Kosuth and Sol LeWitt (Alberro, 2003). Siegelaub is also remembered by art history as a theoretician of information and a documentalist (Alberro, 2001). Siegelaub described his exhibition catalogues as "containers of information," in which "the catalogue can act as primary information for the exhibition, as opposed to secondary information about art” (Harrison and Siegelaub, 1970/1999, p. 199, emphasis original). Anticipating Buckland's (1991) description of tangible information, or 'information-as-thing', Siegelaub’s catalogues are physical units of information, which represent the intangible information behind conceptual works of art.

The radical propositions of conceptual art demanded new forms of information. For this reason, Michael Buckland's account of 'information-as-thing' can provide a model for understanding this problematical art. For Buckland, information has three components: information-as-process, information-asknowledge, and information-as-thing. This construct describes a model in which information is composed of intangible and tangible elements. There is a strong semiotic basis to Buckland's formulation. Information-as-process and information-as- 
knowledge are conceptual in nature, and therefore intangible. Information-as-thing, on the other hand, is a discernible entity, in which conceptual information is made communicable in an objective format. Thus,

\begin{abstract}
A key characteristic of "information-as-knowledge" is that it is intangible: one cannot touch it or measure it in any direct way. Knowledge, belief, and opinion are personal, subjective, and conceptual. Therefore, to communicate them, they have to be expressed, described, or represented in some physical way, as a signal, text, or communication. Any such expression, description, or representation would be “information-as-thing” (Buckland, 1991, p. 351).
\end{abstract}

\title{
Conceptual art and documentation: material characteristics
}

Seth Siegelaub did not define himself as an artist as such. And yet, his close cooperation with artists did verge on creative collaboration (Norvell and Siegelaub, 2001, p. 32). Siegelaub’s participation in art projects was certainly unique, at least compared to other art dealers active in the New York art world of this period. In the words of Lucy Lippard (1973/1997, p. ix), his contemporary and a fellow key figure of the conceptual art movement, Siegelaub “reinvented the role of the 'art dealer' as distributor extraordinaire". Siegelaub "bypassed the art world with exhibitions that took place outside of galleries and/or New York and/or were united in publications that were art rather than merely about art” (Lippard, 1973/1997, p. ix). Siegelaub’s publications are his greatest legacy. These documents, which he called “catalogues”, were intended to make conceptual works of art widely available in a portable and tactile format. The catalogue, Douglas Huebler: November 1968, is typical of 
Siegelaub’s modus operandi. This was the first “exhibition” organized by Siegelaub in which the catalogue functioned as the exhibition. No physical works of art were displayed for the entire duration of this show. The "exhibition” was held in a private apartment, as opposed to a gallery space. Douglas Huebler's art, which took the form of written statements, maps, diagrams and photographs, had no physical aspect beyond the printed catalogue. Huebler explained the documentary nature of his art in a famous conceptual art statement from 1969:

The world is full of objects, more or less interesting; I do not wish to add any more. I prefer, simply, to state the existence of things in terms of time and/or place. More specifically, the work concerns itself with things whose interrelationship is beyond direct perceptual experiences. Because the work is beyond perceptual experience, awareness of the work depends on a system of documentation. This documentation takes the form of photographs, maps, drawings and descriptive language (Huebler, 1969, page unnumbered).

Douglas Huebler: November 1968 became the first example of a 'freestanding catalogue.' The Huebler project provided a formula that Siegelaub would refine and replicate, before his premature retirement from the New York art world in 1972. In an interview in 2004, Siegelaub recalled the significance of the Huebler catalogue:

And so you didn't have to go any further; you didn't have to go to a space to see a Huebler, it was presented to you and me in the format of a book-which obviously led me to work on the idea of the book as an exhibition space, if you like (Slyce and Siegelaub, 2009, p. 5). 
Huebler was quite unique among conceptual artists of this period. Others, including Sol LeWitt and Joseph Kosuth, continued to produce works of art that had physical components. LeWitt's fabricated structures and Kosuth’s photographs and mounted photostats were exhibitable in a gallery setting, not unlike conventional painting and sculpture. Despite this, however, both artists were adamant that the physical dimension was of secondary importance to the primary, conceptual dimension or their work. Other artists, like Robert Barry and Lawrence Weiner, had all but renounced the work of art as a material entity. Weiner's art took a linguistic turn, and was increasingly communicated in the form of written statements. Lawrence Weiner: Statements, December 1968, published by Siegelaub as an artist's book, consisted of twenty-five statements about art.

Of the artists associated with Siegelaub, Robert Barry’s art was arguably the most enigmatic. In terms of documentation, it was also the most ambiguous. In a work called Inert Gas Series, Barry released gasses from pressurised gas canisters into the atmosphere. This one-person exhibition was held at a location near Los Angeles in April 1969, under the title of Inert Gas Series/Helium, Neon, Argon, Krypton, Xenon/From a Measured Volume to Indefinite Expansion. Although Barry took photographs of this event, the invisible gasses were undetectable on film, and therefore no visual evidence of this work exists. No catalogue was produced for this piece. Instead, Siegelaub printed a publicity poster, which contained the name of the work and a phone number. This number connected the caller to an answering service and a recorded message, which described the work in detail (Alberro, 2003, p.118). 
With works like Inert Gas Series, Barry and Siegelaub were deliberately pushing the limits of materiality, as well as the limits of documentation. It is tempting to dismiss the more cryptic manifestations of conceptual art as gimmickry, as novelty for its own sake. To appreciate the documents of conceptual art, it is therefore important to understand something of the movement that produced these documents. Before continuing further, some background and context might be helpful. What motivated conceptual artists to abandon painting and sculpture and to produce works of art of this type? Moreover, how did conceptual art come to dominate the advanced art practice of the late modern period, from approximately 1965 to 1975 ?

\section{Conceptual art and Seth Siegelaub: some background and context}

Art historian Alexander Alberro (1999, pp. xvi-xvii) identifies four art-historical genealogies, or tendencies, that led to the increasing conceptualization of artistic practices in the 1960s. The first of these concerns the "de-emphasization” of art's hierarchical value system. By emphasizing process, and de-emphasizing the importance of the work of art as a cohesive and singular thing, this trajectory "problematizes and dismantles the integral elements of the traditional structure of the artwork”. The second trajectory concerns the reductive “dematerialization of the actual [physical] work of art”. As the importance of art's visual elements diminish, the prominence of textual elements grow. The "de-aestheticization" of the work of art marks the third trajectory. Here, "the negation of aesthetic content” can be traced to the work of Marcel Duchamp and other art historical antecedents. De-aestheticization, says Alberro, "places art at the threshold of information.” The forth trajectory problematizes placement. For example, artists prefer the neutral locations of 
architectural and natural surroundings to the gallery space, which mediates aesthetic contemplation. The documentary format enabled works of art to be distributed and circulated beyond the gallery setting.

It is important to note that these tendencies were not generalizing characteristics, invented by art historians to describe conceptual art. On the contrary, conceptual art was a highly self-conscious and self-reflexive movement, acutely aware of its philosophical and art historical origins (Kosuth, 1969/1999). Lucy Lippard and John Chandler (1968/1999) first coined the phrase the 'dematerialization of art' in 1968. In 1973, Lippard used this term as the title of her definitive anthology of the period, Six Years: The Dematerialization of the Art Object from 1966 to 1972. When reflecting on the history of this movement in a later edition of her foundational study, Lippard (1973/1997, p. vii) wrote: “conceptual art, for me, means work in which the idea is paramount and the material form is secondary, lightweight, ephemeral, cheap, unpretentious and/or 'dematerialized'”. Writing in 1970, art critic Harold Rosenberg (1970/1999, p. 221) spoke of contemporary art’s aesthetic withdrawal, or its de-aestheticization, "as both a reaction against and a continuation of the trend towards formalistic over-refinement in the art of the sixties”.

Formalism dominated art history and criticism for much of the twentieth century. It sought to establish objective criteria for evaluating works of art, based on art’s formal (visual and material) elements (Fry, 1920/1982). Clement Greenberg, the influential art critic, used formalist criteria to champion the prominent movements of the New York school, most notably Abstract Expressionism in the 1950s and PostPainterly Abstraction in the 1960s. In his manifesto essay 'Modernist Painting', 
Greenberg (1965/1982) described painting as the most advanced form of modern art. By relieving itself of the burden of representation and the illusion of threedimensionality, painting was free to explore the intrinsic 'painterly' properties of its medium. Painting's autonomy would invariably lead to pure abstraction, which for Greenberg and the modernist establishment was the culmination of modern art. Thus, de-aestheticization was a strategy for opposing formalist orthodoxy, especially the rhetoric espoused by Clement Greenberg in support of abstract painting.

Compared to other modern art movements, conceptual art can seem perplexing, if not deliberately abstruse. And yet, paradoxically, its printed material is conspicuously plain and ordinary. In the words of Lucy Lippard (1973/1997, p. xvi), “austerity took precedence over hedonism, even to the point of deliberate 'boredom””. When compiling her anthology of conceptual art documents, Lippard (1973/1997, p. xvi) notes the "fascination with pseudo-scientific data and neo-philosophical gobbledygook”. Conceptual artists were drawn to the rational documents of scientific and bureaucratic administration because they seemed impersonal and anonymous. This appealed, in particular, to a movement suspicious of charisma and the excesses of personal expression, as typified by heroic modernists like Jackson Pollock and Barnett Newman. As well as a propensity for dullness, conceptual art documents were made to look cheap. Cheapness complicated the artwork's commodity status in the art market system.

Seth Siegelaub’s Xerox Book, from 1968, is a case in point. For this piece, Siegelaub invited seven artists to utilize a Xerox photocopy machine to create a lowcost work of art, one intended for widespread distribution. At this time, xerography 
was a new technique containing untapped art-making potential. Siegelaub had planned to print an edition of 1,000 copies of the Xerox Book on an office photocopier. However, and somewhat ironically given its title, the cost of photocopying the Xerox Book proved too expensive. Instead, the edition was printed using commercial offset lithography. Despite this, the Xerox Book was printed to resemble a photocopied document, and is synonymous with this technology. The Xerox Book is typical of Siegelaub’s entrepreneurial approach to art dealership. It sold for the modest price of twenty dollars a copy (Ismail-Epps, 2016, p.261).

Many conceptual art documents mimicked the technical specifications of scientific communication. Graphs, maps and diagrams impart visual information. When illustrations are reproduced, they tend to be low-resolution black-and-white photographs, taken with little regard for composition or artistry. Douglas Huebler (1970, page unnumbered) described his photographs as “documents of appearance” and the camera "as a duplicating device whose operator makes no aesthetic decisions”. Like photography, written information is literal and factual. Artists' statements account for most of the written content in conceptual art catalogues. These statements allow artists to communicate their ideas and processes directly to the reader. In contrast to the expressive rhetoric of art criticism, this writing is characterized by a detached, quasi-scientific style. As remarked by Alexander Alberro (2003, p. 74), the laconic language of conceptual art is "conspicuous for its negation of all poetic and metaphorical connotations”. In a work from 1969 called Sentences on Conceptual Art, Sol LeWitt (1969/1999, p. 107) succinctly articulates conceptualism’s philosophy of art and language: “If words are used, and they proceed 
from ideas about art, then they are art and not literature; numbers are not mathematics”.

As well as supporting conceptual art's de-aestheticizing strategy, exhibition catalogues were intended to perform practical, documentary functions. Catalogues were designed to document evidentiary connections between ideas, events and phenomena. Students of document theory will recognize some key documentalist themes with regard to conceptual art practices. Michael Buckland's (1997) account of Suzanne Briet's evidentiary theory of documentation is an obvious point of reference. Buckland (1997, p. 806) translates Briet’s definition of a document as “any physical or symbolic sign, preserved or recorded, intended to represent, to reconstruct, or to demonstrate a physical or conceptual phenomenon”. As it stands, this definition is highly applicable to conceptual art documents. Also, as will be seen in the following section, it closely accords with Seth Siegelaub’s theories of information.

\section{Primary and secondary information}

In early 1970, the editors of Arts Magazine invited four conceptual artists to submit any document, not exceeding one page, for inclusion in the April 1970 issue. Lawrence Weiner, Daniel Buren, Mel Bochner and Sol LeWitt submitted typed and handwritten statements; only Bochner's contribution contained a visual component. While this exercise demonstrated the central importance of text-bearing documents in conceptual art, it also revealed its radical potential to disrupt the status quo. Information of this type raised questions about the validity of art magazines, which had traditionally been based on the separation of information about art (as criticism 
and reportage) and reproductions of art (as photographs of paintings and sculpture). Thus, the boundaries between art and information were blurred. Now, it was noted,

The texts themselves have become the art, and the traditional device of using photographic reproductions in art magazines has been mocked. After all, in this instance, the artworks are not reproductions; the pages that follow are the works of art. There are no more reproductions. There is no more criticism. No more aesthetics. Only art (Battcok, 1973, p. 174).

When Suzanne Briet famously raised the possibility that an antelope could function as a document, she identified this zoological specimen as an example of a primary document. The primary document, the antelope, differed from documents in the zoological literature about the antelope, as well as photographs and sound recordings of the animal, which she classified as examples of secondary documents. Thus, as Briet (1951/2006, p.11) saw it, “the catalogued antelope is an initial document and the other documents are secondary or derived”. When distinguishing these different documentary categories, Briet described catalogues as model forms of secondary documentation. Hence, “current catalogues, retrospective catalogues, and union catalogues are obligatory documentary tools, and they are the practical intermediaries between graphical documents and their users; these catalogues of documents are themselves documents of a secondary degree” (Briet, 1951/2006, p. 11). Briet's classes of documentation, consisting of primary documents and obligatory documentary tools, will be familiar to art historians and curators. To extend Briet's model to the realm of art: works of art are primary documents, whereas art catalogues are secondary documents. 
In total, there are three principal types of scholarly art catalogue (Pointon, 2014, pp. 122-25). The catalogue raisonné is an authoritative listing of an individual artist's complete creative output, or oeuvre. It is concerned with questions of attribution, and discriminates between an artist's original works and copies or forgeries. Catalogues raisonné are the traditional tools of connoisseurship, which is the expert appraisal of works of art, usually for the purpose of determining authenticity and quality. The permanent collection catalogue is the second type of art catalogue frequently encountered by students and scholars of art. Permanent collection catalogues record the holdings of a collecting institution. These catalogues tend to follow art historical classifications, in which, for example, collections are divided by national schools (French painting) or subdivided by medium (Chinese ceramics) or periods (Renaissance drawings). Martin Davies’ catalogues of the old master collections of the National Gallery in London are exemplars of collectionbased documentation (Davies, 1961; Davies, 1968).

Exhibition catalogues are the third, and still the most widespread, type of art catalogue. Traditionally, exhibition catalogues were not accorded the same authority and respect as catalogues raisonné and permanent collection catalogues. Before the age of gallery audio-guides and multimedia information panels, exhibition catalogues were designed with a clear purpose in mind. These documents were used to navigate the gallery space when viewing works of art. This application would determine the basic format and function of exhibition catalogues for decades (Cannon-Brookes, 1985). Exhibition catalogues were essentially exhibition checklists. Although collected as aides-memoire or commemorative keepsakes, most were ephemeral and 
cheaply produced. This changed in the late twentieth century, when art museums strove to make art more widely accessible to new mass audiences. Even in the digital age, exhibition catalogues continue to be produced in hardcopy format. Digital media, including exhibition webpages, have tended to complement, rather than replace, printed catalogues. The exhibition catalogue enjoys a special status in art museum merchandising, where catalogue size is a measure of blockbuster status (West, 1995). The proliferation in glossy colour illustration was responsible for the catalogue's physical transformation, a trend that saw these documents outgrow their function as portable checklists (Lutz, 1999; Cole, 1993).

Alfred H. Barr, the foundation director of the Museum of Modern Art (MoMA) in New York, was among the first museum professionals to realize the exhibition catalogue's information potential. Barr used exhibition catalogues to promote modern art and to support MoMA's reputation as the leading art museum in this field (Kantor, 2002). The catalogues he wrote for key exhibitions, including Cubism and Abstract Art (1936), Picasso: Fifty Years of His Art (1946) and Matisse: His Art and His Public (1951), became classic studies of modernism. Barr’s catalogues were meant to contribute to art-historical knowledge. Augmented with generous illustration and documentation, they were much more than ephemeral checklists of temporary exhibitions. As well as supporting MoMA’s corporate mission, of constructing a narrative history of the modern movement, these catalogues were also expected to convert a sceptical public to the modernist cause. Barr’s catalogues were unapologetically didactic. To quote his biographer: 
More than reliable information, Barr's catalogs also contained a subtle subtext pleading for understanding and further study of puzzling art. But, like a master evangelist, he inserted the message so adroitly that the reader absorbed it along with the fascinating facts (Marquis, 1989, p.92).

The exhibition catalogue's potential for widespread distribution enabled the 'puzzling' art of modernism (and later conceptualism) to be broadly communicated, beyond the confines of the art world. Siegelaub was aware of the possibilities afforded by catalogues for diffusing information about new art. As he noted, "far more people will see a catalogue/exhibition or a catalogue of an exhibition than will see the exhibition itself, if there is one” (O’Neill and Siegelaub, 2014, p. 74). Siegelaub had evidently learned from the experiences of Alfred H. Barr. Although Barr's catalogues never threatened the primacy of the artworks they documented, they did transcend the spatial and temporal confinements of their exhibition events. Barr's catalogues were 'containers of information' and were expected to outlast the exhibitions for which they were made. Also, as Barr demonstrated, a richly illustrated catalogue had the capacity to function as a substitute exhibition, able to be disseminated more widely than the show itself.

Most art catalogues, including exhibition catalogues, have one thing in common: they reinforce the distinction between primary document and secondary document. As secondary documents, art catalogues describe primary works of art. A typical catalogue entry describes an artwork's physical characteristics, usually its medium, measurements and markings, including evidence of authorship, such as the presence of an artist's signature. In addition to descriptive records, catalogues might 
contain contextual information about an artwork's provenance (a comprehensive record of ownership), its exhibition history, and instances where the work has been referenced or reproduced in other secondary sources, including scholarly monographs or journal articles.

Siegelaub's views on art and information have more in common with the documentalist tradition than with the art historical tradition. Pioneers of documentation, notably Paul Otlet, had earlier extended the definition of 'document' to include works of art, which with other artefacts provided evidence of human activity (Buckland, 1997, p. 806). However, the concept of information was more narrowly defined by academic art history. Information was closely associated with art's subject matter, as opposed to its visual elements, such as style. Art historians garnered meaning from works of art by interpreting their images, or iconography (Panofsky, 1955). Siegelaub devised his own theory of information, which like Briet's was based on primary and secondary categories. The most interesting feature of this theory was Siegelaub’s tendency to view all aspects of art as sources of information. An artwork's information-bearing properties included physical and formal elements, such as colour, scale, medium and location, as well as subject matter. Siegelaub’s notion of information therefore accommodates the visual components of abstract (or non-representational) painting and sculpture. In an interview from 1969, Siegelaub remarked:

Before, meaning ten years ago, you could have said art was about information. Except the information before had to do with color, line, composition, and all 
that bullshit, in which case the art and the presentation of the art were identical (Norvell and Siegelaub, 2001, pp. 33-34).

Siegelaub described his catalogues as containers of information, and viewed exhibition catalogues as "the most neutral means to present the new art". This was compared to other secondary sources, especially art magazines and criticism, in which "the photograph or verbalization of the work is a bastardization of the art” (Harrison and Siegelaub, 1970/1999, p. 199). The exhibition catalogue was favoured by conceptual artists because, to quote Siegelaub, "it was a logical outgrowth of the artwork itself” (O’Neill and Siegelaub, 2014, p. 74). However, instead of perpetuating the primary/secondary information distinction, Siegelaub devised strategies that would subvert, or at least complicate, the catalogue’s traditional subordinate relationship to the primary work of art. When working with artists on conceptual art projects, the catalogue would fulfil the role of primary information. As Siegelaub explains, "when art concerns itself with things not germane to physical presence, its intrinsic communicative value is not altered by its presentation in printed media” (Harrison and Siegelaub, 1970/1999, p. 199). He pursued this point to its logical conclusion, producing exhibitions in which the catalogue functioned as the sole material support.

As previously noted, Douglas Huebler, November 1968, was the first example of an exhibition in which primary (physical) artworks were replaced by catalogue information. This project was devised as a site-specific sculpture exhibition. The catalogue contains street maps of New York and Boston, over which shapes (hexagons and squares) have been superimposed. These configurations are used to 
pinpoint the locations, or markers, of so-called 'site sculptures'. Of course, no physical sculptures existed at the 'site sculpture' locations marked on the maps. Dull black-and-white photographs, taken at these sites, show empty street scenes. There was no way to know about these 'site sculptures' without the information contained in the catalogue. As Huebler explains in his cryptic catalogue introduction:

The existence of each sculpture is documented by its documentation. The documentation takes the form of photographs, maps, drawings and descriptive language. The marker 'material' and the shape described by the location of the markers have no special significance, other than to demark the limits of the piece. The permanence and destiny of the markers have no special significance (Huebler, 1968, unnumbered page).

The Xerox Book, from December 1968, followed the same principle, in that the catalogue was designed as a standalone exhibition. There was no concurrent exhibition event. For this project, Siegelaub asked seven artists (Carl Andre, Robert Barry, Douglas Huebler, Joseph Kosuth, Sol LeWitt, Robert Morris, and Lawrence Weiner) to each use a Xerox photocopier machine to create a printable artwork not exceeding twenty-five pages. The seven individual artworks were then combined to produce a group exhibition, in book form. Although, as noted above, the Xerox Book was printed in offset, its photocopied appearance was unaffected. The grainy black and white effects of the photocopying process were faithfully preserved, and the edition was printed on standard Letter size ( 8 1/2" x 11") photocopy paper. With projects like Xerox Book, Siegelaub had devised a format in which works of art could 
be produced and distributed, at relatively low cost, as primary information. As he explained:

For the kind of work that these artists were making and the ideas they were dealing with, the catalogue could function as something very different because the information it contained was primary information. It wasn’t information about something that was somewhere else, it was all there in front of you; it didn't have to be bigger or smaller or in colour. This is what I probably meant by a 'container of information'. For example, the Xeroxbook was primary information. This was the intention behind many of my publication projects (O’Neill and Siegelaub, 2014, p. 70).

Even when catalogues were related to temporary exhibition events, such as January 5-31, 1969 (The January Show), they were conceived as primary information. This landmark show inverted the conventional relationship between the catalogue and the exhibition. In this instance, the catalogue was the primary document and the objects exhibited with the catalogue were secondary documents. The January Show was a group exhibition comprising works by Robert Barry, Douglas Huebler, Joseph Kosuth, and Lawrence Weiner. For this event, held in early 1969, Siegelaub rented two rooms in a New York office building. The first room housed the catalogue, which communicated the exhibition's ideas, while the other room housed additional objects, which were supplementary to the catalogue. Since works by Huebler and Weiner were written statements, they were only available in the catalogue in a textual format. Barry's contributions were the most challenging pieces in The January Show. Five of his works were based on inaudible sound waves transmitted on radio 
equipment concealed behind an office closet. The technical specifications of each transmission were recorded in the catalogue, for example: 88 mc Carrier Wave (FM), 88 megacycles; 5 milliwatts, 9-volt DC battery. Barry’s imperceptible sound installations, known as the Carrier Wave series, were unknowable without the catalogue information.

\section{Placement and meaning: from art to document}

Thus far, this paper has discussed Siegelaub’s conceptual art catalogues in relation to Buckland's theory of information, which is composed of a tangible dimension (information-as-thing) and intangible categories consisting of information-asknowledge and information-as-process. Buckland's theory is applicable to conceptual art documents because the printed "thing" provides a material base for the immaterial (conceptual) elements essential to this type of art. However, as demonstrated by Robert Barry’s Inert Gas and Carrier Wave projects, Siegelaub’s documents were also intended to function as evidence. Barry's art, which often contained no physical or perceptible objects, was heavily dependent on documentary proof.

This paper will conclude with a discussion of Bernd Frohmann’s (2009) critique of Buckland's definitional accounts of documentation. As will be seen, the example of conceptual art both confirms and challenges key issues raised in the documentation literature, especially debates pertaining to the document's evidentiary attributes. Frohmann questioned the value of attaching definitive characteristics to documents. Aside from specific instrumentalist purposes, he argued there is no compelling philosophical case for asking the question, what is a document? Instead of 
proposing definitions, especially those based on Suzanne Briet's treatise on documentation, Frohmann suggested an approach in which analogy, similarity and resemblance could be used to identify instances of documentation. Narratives, or stories about things, would enable new examples to be introduced and made recognizable as documents. Thus, things would not need to fulfil particular criteria in order to be admitted to the realm of document. When it comes to identifying things as documents, place and setting would play a crucial role in framing these interpretations. Frohmann used cabinets of curiosities to illustrate his argument. Cabinets of curiosities were popular among the English and European virtuosi of the sixteenth-century. These assemblages enabled Frohmann to demonstrate how, under certain conditions, documents could defy prevailing definitions, especially those that supported the document's connections to fact or evidence.

Thus, cabinets of curiosities enabled Frohmann to demonstrate how a thing's placement and setting can affect its documentary status. A document's capacity to impart fact and evidence, for example, did not originate from any immanent quality intrinsic to the document-as-thing. Rather, this documentary power was contingent on factors such as location and context. Cabinets of curiosities were illustrative of this process because they provided an historical example of a setting in which things were deliberately deprived of their information-bearing properties. "Some places," says Frohmann (2009, p. 297), “rather than encouraging statements, claims, and propositions about the things in them, were designed to deliberately constrain, limit, and inhibit them”. The cabinet was not just a spatial enclosure in which curios were housed and exhibited. It was a social and intellectual milieu, which cultivated a particular way of looking at things. Cabinets emphasized the peculiar and unnatural 
qualities of their objects, as opposed to their scientific or empirical significance. As Frohmann explains:

They were not intended to inform in Otlet or Briet's sense; they were not displayed to generate evidentiary connections to other objects, especially not, as the material equivalents of Baconian facts, to theories or generalizations. They lack, or at least constrict, what Ron Day, in his interpretation of Briet, calls “indexicality”. Their power was directed elsewhere, towards policing quite specific discursive exclusions (2009, p. 297).

Rather than being a forerunner of the modern museum, the cabinet of curiosities could more accurately be described as the precursor of the modern art gallery. The 'speechless wonder' and contemplative silence, which according to Frohmann greeted these cabinets, evokes the Kantian notion of disinterested judgment, a fundamental principle of philosophical aesthetics. The aesthetic appreciation of works of art, as autonomous things, was a uniquely modern idea (Eagleton, 1990). Larry Shiner (2001) dates the origins of the modern concept of art from the eighteenth-century. Beauty was synonymous with the aesthetic value of art throughout much of the nineteenth-century. In the twentieth-century, when beauty ceased to be a guiding ideal, 'significant form' became an aesthetic quality. The aesthetic outlook differed from historical ways of looking at art. Before the advent of the aesthetic ideology, works of art were made with the intention of performing ritual and social functions (Belting, 1994). For millennia, art embodied information and sought to establish connections between ideas and things. 
The aesthetic gaze eschewed utility and subordinated the artwork's subject matter to its formal, self-referential elements. Like the cabinet of curiosities, the aesthetic sphere was maintained by a system of 'discursive exclusions'. These parameters were cultural as well as spatial. Just as the Panopticon prison established a powerful epistemological connection with surveillance and modern disciplinary knowledge, the modern 'white cube' gallery was a discursive apparatus of the aesthetic gaze (Preziosi, 1989, p. 62). In the words of art critic Brian O’Doherty (1999, p. 14), “the ideal gallery subtracts from the artwork all cues that interfere with the fact that it is 'art.' The work is isolated from everything that would detract from its own evaluation of itself”. The modern gallery space was an exclusionary technology, much like the cabinet of curiosities. It imposed restrictions on art-asinformation, by reducing artefacts to things of pure form. For this reason, documentation was essential to conceptual art's de-aestheticizing strategy.

Conceptual art was a movement that challenged the aesthetic authority of the autotelic work of art. Conceptual artists replaced art, as autonomous form, with art-asinformation. Siegelaub used the document format for his radical projects precisely because it was a technique for recording facts and evidence, for re-establishing connections between art and information. Conceptual art did not just imitate, or parody, the appearance of technical, administrative and scientific communication. Rather, for Siegelaub and conceptual artists, the document was a way of dissolving aesthetic and material hierarchies, which under modernism had prevented art from performing an informational role in society. As Alexander Alberro explains: 
Altogether, then, we see in 1969 very real concerns about a slippage from art to document that parallels the more general theoretical shift during the period away from art as autonomous to the perception that all cultural products function on the same plane, without depth, hierarchy, and intrinsic value or meaning (2001 p. 12).

\section{Conclusion: towards a reconciliation of art and information}

To date, the common ground between art and documentation has been explored almost exclusively from the perspective of art history. This paper has attempted to redress this imbalance by examining conceptual art from the perspective of document theory. It has shown that Siegelaub’s theories of information have much in common with the documentalist tradition. It has argued that his work is important, and not just for its potential to contribute to the literature of document theory. More importantly, this paper has sought to establish a dialogue between art history and documentation studies, thereby demonstrating potential for further cross-disciplinary collaboration.

However, this paper has also revealed some points of difference. Whereas Buckland (2014, p. 185) considered information-as-thing to be an open category, and stressed the importance of extending the realm of document to include a diverse range of signifying things, Siegelaub wanted his catalogues to adhere to a conventional definition of documentation, as inscribed or printed information. Siegelaub was preoccupied with the text-bearing nature of documents, so much so that he designed his catalogues to look and feel quintessentially document-like. 
Documents also played a crucial role in the dematerialization process, which in the 1960s saw conceptual artists abandon traditional artistic media in favour of textual media. The document enabled conceptual artists to extend the work of art beyond its physical dimensions. However, despite rejecting the work of art's formal elements, conceptual artists never totally renounced the corporeal. Art's conceptual dimension could not be communicated without the material support of information media, or information-as-thing. Thus, when Siegelaub’s catalogues acted as primary information for conceptual exhibitions, they effectively became exhibitions in printed form. It therefore follows that conceptual art catalogues were more than mere metaphors for absent works of art; the Xerox Book is both a document and a work of art. These practices were designed to transgress the ontological boundaries that had separated art and information in the modern era. This was not achieved by making documents look more like works of art, through stylization or aestheticization. Rather, it was achieved by making artworks look more like documents, as emblems of information. It did not matter if these documents were dull, cheaply produced, or indeed incomprehensible. The document format was prized for its transparency and factual neutrality, for its potential to reconcile art and information.

\section{References}

Alberro, A. (1999), “Reconsidering Conceptual Art, 1966-1977”, in Alberro, A. and Stimson, B. (Ed.), Conceptual Art: a critical anthology, MIT Press, Cambridge, Mass., pp. xvixxxvii.

Alberro, A. (2001), “At the threshold of art as information”, in Alberro, A. and Norvell, P. (Ed.), Recording Conceptual Art: early interviews with Barry, Huebler, Kaltenbach, LeWitt, Morris, Oppenheim, Siegelaub, Smithson and Weiner, University of California Press, Berkeley, pp. 1-15.

Alberro, A. (2003), Conceptual art and the politics of publicity, MIT Press, Cambridge, Mass. 
Battcock, G. (1973), “Documentation in conceptual art”, in Battcock, G. (Ed.), Idea art: a critical anthology, Dutton, New York, pp. 174-183.

Belting. H. (1994), Likeness and presence: a history of the image before the era of art, University of Chicago Press, Chicago.

Berger C. and Santone, J. (2016), “Documentation as art practice in the 1960s”, Visual Resources, Vol. 32 No. 3-4, pp. 201-209.

Berrebi, S. (2014), The shape of evidence: contemporary art and the document, Valiz, Amsterdam.

Briet, S. (1951/2006), What is documentation?: English translation of the classic French text by Ronald E. Day, Laurent Martinet with Hermina G.B. Anghelescu, Scarecrow Press, Lanham, Md.

Buckland, M.K. (1991), "Information as thing”, Journal of the American Society for Information Science, Vol. 42 No. 5, pp. 351-360.

Buckland, M.K. (1997), “What is a 'document'?”, Journal of the American Society for Information Science, Vol. 48 No. 9, pp. 804-809.

Buckland, M. (2014), “Documentality beyond documents”, The Monist, Vol. 97 No. 2, pp. 179-186.

Cannon-Brookes, P. (1985), “The evolution of the art exhibition catalogue and its future”, Art and Artists, No. 220, pp. 22-27.

Carroll, N. (1993), "Historical narratives and the philosophy of art”, Journal of Aesthetics and Art Criticism, Vol. 51 No. 3, pp. 313-326.

Cole, B. (1993), “Catalogues of Abuse”, Museum News, Vol. 72 No. 4, pp. 48-49.

Davies, M. (1961), The earlier Italian schools, National Gallery, London.

Davies, M. (1968), Early Netherlandish school, National Gallery, London.

Eagleton, T. (1990), The ideology of the aesthetic, Blackwell, Oxford.

Frohmann, B. (2009), “Revisiting 'what is a document?'”, Journal of Documentation, Vol. 65 No. 2, pp. 291-303.

Fry, R. (1920/1982), “An essay on aesthetics”, in Frascina, F. and Harrison, C. (Ed.), Modern art and modernism: a critical anthology, Paul Chapman, London, pp. 79-87.

Gorichanaz, T. and Latham, K.F. (2016), “Document phenomenology: a framework for holistic analysis”, Journal of Documentation, Vol. 72 No. 6, pp. 1114-1133.

Greenberg, C. (1965/1982), “Modernist painting”, in Frascina, F. and Harrison, C. (Ed.), Modern art and modernism: a critical anthology, Paul Chapman, London, pp. 5-10. 
Harrison, C. and Siegelaub, S. (1970/1999), “On exhibitions and the world at large”, in Alberro, A. and Stimson, B. (Ed.), Conceptual Art: a critical anthology, MIT Press, Cambridge, Mass., pp. 198-204.

Huebler, D. (1968), November 1968, Seth Siegelaub, New York.

Huebler, D. (1969), “Untitled statement”, in Siegelaub, S. (Ed.), Barry, Huebler, Kosuth, Weiner: January 5-31, 1969, Seth Siegelaub, New York.

Huebler, D. (1970), Location piece \#2: New York City, Seattle, Washington, Multiples, New York.

Ismail-Epps, S. (2016), “Artists’ pages: a site for the repetition and extension of Conceptual Art”, Visual Resources, Vol. 32 No. 3-4, pp. 247-262.

Jones, A. (1997), “'Presence’ in absentia: experiencing performance as documentation”, Art Journal, Vol. 56 No. 4, pp. 11-18.

Kantor, S.G. (2002), Alfred H. Barr, Jr., and the intellectual origins of the Museum of Modern Art, MIT Press, Cambridge, Mass.

Kosuth, J. (1969/1999), “Art after philosophy”, in Alberro, A. and Stimson, B. (Ed.), Conceptual Art: a critical anthology, MIT Press, Cambridge, Mass., pp. 158-177.

Latham, K.F. (2014), “Experiencing documents”, Journal of Documentation, Vol. 70 No. 4, pp. 544-561.

LeWitt, S., (1969/1999), “Sentences on conceptual art”, in Alberro, A. and Stimson, B. (Ed.), Conceptual Art: a critical anthology, MIT Press, Cambridge, Mass, pp. 106-108.

Lippard, L.R., (1973/1997), Six years: the dematerialization of the art object from 1966 to 1972, University of California Press, Berkeley.

Lippard, L.R. and Chandler, J. (1968/1999), “The Dematerialization of art”, in Alberro, A. and Stimson, B. (Ed.), Conceptual Art: a critical anthology, MIT Press, Cambridge, Mass., pp. 46-51.

Lund, N.W. (2009), “Document theory”, Annual Review of Information Science and Technology, Vol. 43 No.1, pp. 399-432.

Lutz, J. (1999), "Printed shows: exhibitions and their catalogues during the last fifty years", Art Libraries Journal, Vol. 24 No. 2, pp. 4-7.

Marquis, A.G. (1989), Alfred H. Barr, Jr.: missionary for the modern, Contemporary Books, Chicago.

Mansfield, E. (2002), Art history and its institutions: foundations of a discipline, Routledge, London. 
Norvell, P. and Siegelaub, S. (2001), “Seth Siegelaub, April 17, 1969”, in Alberro, A. and Norvell, P. (Ed.), Recording Conceptual Art: early interviews with Barry, Huebler, Kaltenbach, LeWitt, Morris, Oppenheim, Siegelaub, Smithson and Weiner, University of California Press, Berkeley, pp. 31-55.

O’Doherty, B. (1999), Inside the white cube: the ideology of the gallery space, University of California Press, Berkeley, Calif.

O’Neill, P. and Siegelaub, S. (2014), “In Honour of the Memory of Seth Siegelaub”, Art \& the Public Sphere, Vol. 3 No. 1, pp. 63-76.

Panofsky, E. (1955), Meaning in the visual arts, University of Chicago Press, Chicago.

Pointon, M. (2014), History of art: a students’ handbook, Routledge, Abingdon.

Preziosi, D. (1989), Rethinking art history: meditations on a coy science, Yale University Press, New Haven.

Rosenberg, H. (1970/1999), “De-aestheticization”, in Alberro, A. and Stimson, B. (Ed.), Conceptual Art: a critical anthology, MIT Press, Cambridge, Mass, pp. 220-223.

Rubin, R.E (2010), Foundations of library and information science, Neal-Schuman, New York.

Santone, J. (2016), “Documentation as group activity: performing the Fluxus network”, Visual Resources, Vol. 32 No. 3-4, pp. 263-281.

Shiner, L. (2001), The invention of art: a cultural history, University of Chicago Press, Chicago, Ill.

Slyce, J. and Siegelaub, S., (2009), “The Playmaker: Seth Siegelaub interviewed by John Slyce”, Art Monthly, June, No. 327, pp. 1-6.

Spieker, S. (2008), The big archive: art from bureaucracy, MIT Press, Cambridge, Mass.

West, S. (1995), “The devaluation of 'cultural capital': post-modern democracy and the art blockbuster,” in Pearce, S. (Ed.), Art in museums, Athlone, London, 80-93. 